\title{
Bottled Poetry
}





\section{Bottled Poetry}

Napa Winemaking

from Prohibition

to the Modern Era

$\sqrt{8}$

James T. Lapsley

UNIVIRSITY OF CALIFORNIA PRESS

Berkeley / Los Angeles / London 
University of California Press

Berkeley and Los Angeles, California

University of California Press, Lrd.

London, England

(O) 1996 by

The Regents of the University of California

Library of Congress Cataloging-in-Publication Data

Lapsley, James T.

Bottled poetry : Napa winemaking from Prohibition to the modern era / James T. Lapsley

p. $\mathrm{cm}$.

Includes bibliographical references and index.

ISBN 0-520-20272-4 (alk. paper)

I. Wine and wine making - California - Napa

Valley-History. I. Title.

TPs57.L35 1996

$641.2^{\prime} 2^{\prime} 0979419-\mathrm{dc} 20$

$96-7072$

Printed in the United States of America

$\begin{array}{lllllllll}9 & 8 & 7 & 6 & 5 & 4 & 3 & 2 & \text { I }\end{array}$

The paper used in this publication meets the minimum requirements of American National Standard for Information Sciences - Permanence of Paper for Printed Library Materials, ANSI Z39.48-1984. 
This book is dedicated with great respect to the memory of three "winemen" and one wine historian:

\section{IIM BEARD}

printer, St. Helenan, and tireless partisan of Napa wine

$$
\text { LOU GOMBERG }
$$

observer, quantifier, and promoter of California wine

ANDRE TCHELISTCHEFF

enologist, educator, and experimenter

RUTH TEISER

preserver of a generation's history 

Wine in California is still in the experimental stage; and when you taste a vintage, grape economical questions are involved. The beginning of vine-planting is like the beginning of mining for precious metals: the wine-grower also "prospects." One corner of land after another is tried with one kind of grape after another. This is a failure; that is better; a third best. So, bit by bit, they grope about for their Clos Vougeot and Lafite. Those lodes and pockets of earth, more precious than the precious ores, that yield inimitable fragrance and soft fire; those virtuous Bonanzas, where the soil has sublimated under sun and stars to something finer, and the wine is bottled poetry: these still lie undiscovered; chaparral conceals, thicket embowers them; the miner chips the rock and wanders farther, and the grizzly muses undisturbed. But there they bide their hour, awaiting their Columbus; and nature nurses and prepares them. The smack of California earth shall linger on the palate of your grandson.

Robert Louis Stevenson, "Napa Wine," in The Silverado Squatters (1880) 
